\title{
Pengaruh Model Problem Based Learning dengan Metode Eksperimen dan Diskusi Terhadap Hasil Belajar Fisika Ditinjau dari Sikap Ilmiah Siswa Kelas X MIPA SMA N 1 Mataram
}

\author{
Muhamad Khairul Azmi ${ }^{1}$, Satutik Rahayu ${ }^{1}$, Hikmawati ${ }^{1}$ \\ ${ }^{1}$ Program Studi Pendidikan Fisika \\ FKIP Universitas Mataram \\ Mataram, Indonesia \\ Email: azmi24041994@gmail.com
}

\begin{abstract}
This study aims to determine: (1) the effect of problem based learning models with experimental methods and discussion on learning outcomes; (2) the effect of Scientific Attitude of students towards learning outcomes; (3) the interaction between the model problem based learning with experimental methods and discussion with scientific attitude of students towards learning outcomes. This type of research is an experimental research study design with Factorial Design $2 \times 2$. Population in research of all $X$ grade student of MIPA at SMA Negeri 1 Mataram academic year 2015/2016. Sampling studies using cluster random sampling, and get class X MIPA 4 as an experimental class I and class X MIPA 7 as experimental class II. The research's instrument used was a multiple choice test with five alternative answers and considering the validity, reliability, power and the level of difficulty depending matter and using scientific attitude questionnaire instrument. This research showed that the average value of posttest experimental class I was 76.50 and the experimental class II at 79.83 with the average value of the value of the scientific attitude to the experimental class I was 52.42 and 50.70 of the experimental class II. Data obtained beforehand tested normality and homogeneity, earned both classes of normally distributed and homogeneous, then followed by hypothesis testing using analysis of variance (ANOVA) with two different cell. The results of this study show that: (1) There is effect problem based learning model with experimental methods and discussion on learning outcomes; (2) Scientific Attitude effected on the student learning outcomes; (3) There is no interaction between the problem based learning model with experimental methods and discussion with scientific attitude towards learning outcomes.
\end{abstract}

Keywords: discussion method, experimental method, learning outcomes, scientific attitude, problem based learning.

\section{Pendahuluan}

Pendidikan merupakan usaha untuk membantu peserta didik mengembangkan seluruh potensinya (hati, pikir, rasa, dan karsa, serta raga) untuk menghadapi masa depan [1]. Hal ini sejalan dengan tujuan pendidikan yang terdapat dalam UndangUndang Sistem Pendidikan Nasional Nomor 20 tahun 2003 menyatakan bahwa, tujuan Pendidikan Nasional adalah untuk berkembangnya potensi peserta didik agar menjadi manusia yang beriman dan bertakwa kepada Tuhan Yang Maha Esa, berakhlak mulia, sehat, berilmu, cakap, kreatif, mandiri, dan menjadi warga negara yang demokratis serta bertanggung jawab. Untuk mencapai tujuan pendidikan tersebut, tentu tidak terlepas dari proses belajar. Proses belajar terjadi karena adanya intraksi antara seseorang dengan lingkungannya [2]. Dalam proses belajar diharapkan dapat mencerminkan tiga aspek dalam kegiatan pembelajaran, yaitu aspek sikap, pengetahuan dan keterampilan. Dikembangkangkannya kurikulum baru, kurikulum
2013, dalam sistem pendidikan nasional, mengupayakan ketiga aspek dalam tujuan pendidikan nasional dapat dilaksanakan dalam setiap proses pembelajaran [3].

Proses pembelajaran pada kurikulum 2013 diselenggarakan secara interaktif, inspiratif, menyenangkan, menantang, memotivasi peserta didik untuk berpartisipasi aktif, serta memberikan ruang yang cukup bagi prakarsa, kreativitas dan kemandirian sesuai dengan bakat, minat dan perkembangan fisik serta psikologis peserta didik. Hal ini sesuai dengan tema pengembangan kurikulum 2013 yaitu kurikulum yang dapat menghasilkan insan Indonesia yang produktif, kreatif, inovatif, efektif melalui penguatan sikap, keterampilan dan pengetahuan yang terintegritas. Sehubungan dengan itu, kurikulum 2013 menerapkan pendekatan saintifik dalam proses pembelajaran.

Pendekatan saintifik merupakan pendekatan di dalam kegiatan pembelajaran yang mengutamakan kreativitas dan temuan-temuan peserta didik. Pengalaman belajar yang mereka proleh tidak bersifat 
indoktrinisasi, hafalan, dan sejenisnya. Pengalaman belajar, baik itu yang berupa pengetahuan, keterampilan, dan sikap mereka proleh berdasarkan kesadaran dan kepentingan mereka sendiri. Pembelajaran dengan pendekatan saintifik dirancang sedemikian rupa agar peserta didik secara aktif mengkontruksi konsep, hukum atau prinsip melalui tahapan-tahapan mengamati (untuk mengidentifikasi atau menemukan masalah), merumuskan masalah, mengajukan atau merumuskan hipotesis, mengumpulkan data dengan berbagai teknik, menganalisis data, menarik kesimpulan dan mengkomunikasikan konsep, hukum atau prinsip yang "ditemukan". Tujuan pembelajaran dengan pendekatan saintifik didasarkan pada keunggulan pendekatan ilmiah. Beberapa tujuan pembelajaran dengan pendekatan saintifik diantaranya untuk membentuk kemampuan siswa dalam menyelesaikan suatu masalah secara sistematik [4].

Pendekatan saintifik sangat sesuai jika diterapkan dalam Pembelajaran Sains (IPA). Sains (IPA) didefinisikan sebagai ilmu yang mempelajari tentang sebab akibat peristiwa-peristiwa yang terjadi di alam. Sains juga dapat diartikan sebagai kumpulan pengetahuan yang sistematis dari gejala-gejala alam. Sains (IPA) juga kadang diartikan sebagai pengetahuan yang sistematis atau tersusun secara teratur berlaku umum dan berupa kumpulan data hasil observasi dan eksperimen [5]. Sains (IPA) ialah suatu cara mencari tahu tentang alam secara sitematis untuk menguasai pengetahuan, fakta-fakta, konsep-konsep, prinsip-prinsip, proses penemuan dan memiliki sikap ilmiah [6]. Dengan kata lain, IPA merupakan kombinasi dari unsur produk berupa pengetahuan dan proses [3].

Fisika sebagai salah satu rumpun ilmu IPA, pada hakikatnya juga terdiri atas aspek produk dan proses. Sebagai sebuah produk, fisika merupakan sekumpulan pengetahuan tentang fakta, konsep, generalisasi, prinsip, teori dan hukum fisika. Sementara sebagai suatu proses, fisika merupakan serangkaian proses ilmiah yang dilakukan dalam menenemukan pengetahuan-pengetahuan tentang fisika. Maka, pemahaman terhadap fisika seharusnya tidak hanya memandang fisika sebagai produk tetapi juga sebagai proses. Dalam proses pembelajaran fisika, kegiatan pembelajaran tidak hanya ditekankan pada aspek produk saja, tetapi juga harus diimbangi dengan aspek proses. Hal ini sejalan dengan tuntutan kurikulum 2013 yang menginginkan agar dalam proses pembelajaran harus terdapat aspek sikap, pengetahuan dan keterampilan.

Berdasarkan hasil observasi yang sudah peneliti lakukan pada siswa kelas X MIPA di SMA Negeri 1 Mataram, terdapat beberapa masalah yang ditemukan pada saat proses pembelajaran. Banyak siswa yang tidak begitu memperhatikan penjelasan guru, mengganggu teman sebelahnya, dan ada pula yang mengantuk. Hal ini terjadi karena proses pembelajaran yang dirancang oleh guru masih belum efektif, baik dari segi model pembelajaran, metode pembelajaran, maupun media pembelajaran.

Sementara itu, hasil wawancara peneliti dengan salah satu guru IPA Fisika di SMA Negeri 1 Mataram, diperoleh informasi bahwa siswa tidak memperhatikan guru, yang ditunjukan dengan adanya beberapa siswa yang main-main sendiri dan terkadang main HP karena di SMA Negeri 1 Mataram siswa di bebaskan untuk membawa HP dalam proses pembelajaran dengan tujuan dapat digunakan sebagai sumber belajar. Namun banyak siswa yang menyalah gunakan HP yang dibawa untuk main-main saja hal ini tentunya tidak menunjukan sikap ilmiah seorang siswa dalam pembelajaran Fisika yang sesuai dengan tuntunan kurikulum 2013. Sementara itu dalam proses pembelajaran guru memang sudah melakukan penilaian sikap siswa. Namun guru tidak pernah memperhatikan sikap ilmiah pada saat proses belajar mengajar. Seharusnya dalam kegiatan belajar mengajar fisika sikap ilmiah penting untuk diperhatikan terlebih bahwa fisika sebagai suatu proses, fisika merupakan serangkaian proses ilmiah yang dilakukan dalam menenemukan pengetahuanpengetahuan tentang fisika. Hal ini tentunya membutuhkan sikap ilmiah dalam mempelajari fisika. Oleh karena itu sikap ilmiah sangat penting untuk di perhatikan oleh guru. Selain itu disebabkan olek faktor yang berasal dari siswa seperti sikap dan minat mereka terhadap pelajaran Fisika, mereka beranggapan bahwa pelajaran Fisika itu sulit, sehingga siswa merasa jenuh dan kurang serius dalam mengikuti proses pembelajaran. Hal ini berdampak pada hasil belajar fisika siswa yang rendah, rata-rata dibawah Kriteria Ketuntasan Minimal (KKM). Adapun KKM untuk mata pelajaran Fisika adalah 70. Data hasil belajar siswa kelas X MIPA SMAN 1 Mataram dapat dilihat pada tabel di bawah ini.

Tabel 1. Nilai Rata-rata Ulangan Tengah Semester Genap Mata Pelajaran Fisika Kelas X MIPA SMAN 1 Mataram

\begin{tabular}{llcll}
\hline No & Kelas & $\begin{array}{l}\text { Nilai } \\
\text { Rata- } \\
\text { Rata }\end{array}$ & $\begin{array}{l}\text { KK } \\
\text { M }\end{array}$ & Keterangan \\
\hline 1. & X MIPA 1 & 49,05 & & $\begin{array}{l}\text { Tidak } \\
\text { Tuntas } \\
\text { 2. }\end{array}$ \\
X MIPA 2 & 62,35 & & $\begin{array}{l}\text { Tidak } \\
\text { Tuntas } \\
\text { Tidak }\end{array}$ \\
3. & X MIPA 3 & 44,80 & 70 & $\begin{array}{l}\text { Tuntas } \\
\text { Tuntas } \\
\text { Tidak } \\
\text { Tuntas }\end{array}$ \\
4. & X MIPA 4 & 72,39 & & \\
\hline
\end{tabular}




\begin{tabular}{llll}
\hline 6. & X MIPA 6 & 73,50 & Tuntas \\
7. & X MIPA 7 & 67,70 & $\begin{array}{l}\text { Tidak } \\
\text { Tuntas }\end{array}$ \\
8. & X MIPA 8 & 55,68 & $\begin{array}{l}\text { Tidak } \\
\text { Tuntas }\end{array}$ \\
\hline
\end{tabular}

(Sumber: Guru Mata Pelajaran IPA Fisika,

2016)

Berdasarkan data tersebut, maka dibutuhkan solusi alternatif yang dapat membantu siswa belajar efektif sehingga akan berdampak pada hasil belajar Fisika siswa. Terlebih lagi SMA Negeri 1 Mataram merupakan salah satu sekolah yang ditetapkan sebagai sekolah yang menerapkan kurikulum 2013 di Nusa Tenggara Barat. SMA Negeri 1 Mataram seharusnya mampu mengimplementasi kurikulum 2013 dengan utuh sesuai dengan tuntutan kurikulum tersebut dalam proses pembelajaran. Namun, hal itu tidak secara utuh diimplementasikan sehingga menimbulkan beberapa permasalahan dalam proses pembelajaran sebagaimana uraian di atas.

Berdasarkan permasalahan di atas, peneliti mengambil suatu alternatif solusi pembelajaran yakni dengan menerapkan model Problem Based Learning (PBL) dengan metode eksperimen dan metode diskusi. PBL merupakan model pembelajaran yang menantang siswa untuk "belajar bagaimana belajar", bekerja secara kelompok untuk mencari solusi dari permasalahan. Dalam PBL, fokus pembelajaran pada masalah yang dipilih sehingga siswa tidak saja mempelajari konsep-konsep yang berhubungan dengan masalah tetapi juga metode ilmiah untuk memecahkan masalah tersebut. Oleh sebab itu, siswa tidak saja harus memahami konsep yang relevan dengan masalah yang menjadi pusat perhatian tetapi juga memperoleh pengalaman belajar yang berhubungan dengan keterampilan menerapkan metode ilmiah dalam memecahkan masalah serta menumbuhkan pola berpikir kritis. Dengan adanya keterampilan menerapkan metode ilmiah dalam mememcahkan masalah maka akan memicu siswa untuk terus giat belajar dan mencari solusi untuk mengatasi setiap permasalahan yang terjadi khususnya dalam pembelajaran fisika. Dengan demikian, diharapkan siswa dapat belajar dengan baik dan berpengaruh pada hasil belajar siswa. Hal ini didukung oleh penelitian yang dilakukan oleh bahwa model problem based learning berpengaruh signifikan terhadap hasil belajar fisika siswa [7].

Fisika sebagai produk, sikap, dan proses dalam pembelajarannya membutuhkan metode pembelajaran yang dapat mengefektifkan proses pembelajaran. Beberapa metode yang cocok digunakan yaitu metode ekpserimen dan metode diskusi. Metode eksperimen merupakan cara penyajian pelajaran di mana siswa melakukan percobaan dengan mengalami dan membuktikan sendiri sesuatu yang dipelajari [8].
Metode diskusi merupakan metode mengajar yang menyajikan bahan-bahan pembelajaran dalam bentuk masalah-masalah yang harus di pecahkan oleh siswa [9]. Fisika juga dikatakan sebagai sikap yang tentunya membutuhkan sikap ilmiah dalam mempelajari fisika. Sikap ilmiah merupakan sikap ingin tahu, respek terhadap data/fakta, berpikir kritis, penemuan dan kreativitas, berpikiran terbuka dan kerjasama, ketekunanan, dan peka terhadap lingkungan sekitar [10].

Kolaborasi antara model problem based learning dengan metode eksperimen dan diskusi diharapkan dapat menciptakan proses pembelajaran yang efektif dan menyenangkan sehingga kesan membosankan dalam pembelajaran fisika dapat teratasi. Selain itu, siswa dapat berperan aktif karena siswa berpartisipasi langsung dalam proses pembelajaran dan diharapkan dapat berpengaruh pada hasil belajar siswa. Hal ini juga didukung oleh hasil penelitian sebelumnya yang dilakukan oleh [11] menyatakan penggunaan model PBL dengan metode eksperimen memberikan pengaruh positif, serta penelitian yang dilakukan oleh [12] menyatakan sikap ilmiah memberikan pengaruh positif terhadap hasil belajar siswa, dalam penelitian ini, Peneliti ingin melihat model problem based learning dengan metode eksperimen atau model problem based learning dengan metode diskusi yang lebih berpengaruh terhadap hasil belajar.

\section{TINJAUAN PUSTAKA}

\section{A. Model Problem Based Learning}

Model problem based learning merupakan sebuah model pembelajaran yang menyediakan pengalaman autentik yang mendorong siswa untuk belajar aktif, mengkonstruksi pengetahuan, dan mengintegrasikan konteks belajar di sekolah dan belajar di kehidupan nyata secara alamiah [13]. Model problem based learning merupakan suatu model pembelajaran yang didasarkan pada banyaknya permasalahan yang membutuhkan penyelidikan autentik yakni penyelidikan yang membutuhkan penyelesaian nyata dari permasalahan nyata [14].

\section{B. Metode Belajar}

\section{Metode Eksperimen}

Metode eksperimen adalah cara penyajian bahan pelajaran di mana siswa melakukan percobaan dengan mengalami untuk membuktikan sendiri sesuatu pernyataan atau hipotesis yang dipelajari [15]. Dalam metode ini, siswa diberi kesempatan untuk mengalami sendiri atau melakukan sendiri, mengikuti proses, mengamati suatu objek, menganalisis, membuktikan dan menarik kesimpulan sendiri tentang suatu objek, keadaan atau proses sesuatu. Peran guru untuk membuat kegiatan ini 
menjadi faktor penentu berhasil atau gagalnya metode eksperimen ini.

Metode eksperimen (percobaan) adalah cara penyajian pelajaran, di mana siswa melakukan percobaan dengan mengalami dan membuktikan sendiri sesuatu yang dipelajari [8]. Metode eksperimen adalah salah satu cara mengajar di mana siswa melakukan suatu percobaan tentang sesuatu hal, mengamati prosesnya serta menuliskan hasil percobaannya, kemudian hasil pengamatan itu disampaikan ke kelas dan dievaluasi oleh guru [16].

\section{Metode Diskusi}

Metode ialah cara untuk mencapai sesuatu, metode pengajaran termasuk dalam perencanaan kegiatan atau strategi [17]. Menurut Kamus Besar Bahasa Indonesia (1995) dalam [18] diskusi adalah pertemuan ilmiah untuk bertukar pikiran mengenai sesuatu masalah.

Diskusi pada dasarnya ialah tukar menukar informasi, pendapat, dan unsur-unsur pengalaman secara teratur dengan maksud untuk mendapat pengertian bersama yang lebih jelas dan lebih teliti tentang sesuatu, atau untuk mempersiapkan dan merampungkan keputusan bersama. Oleh karena itu, diskusi bukan debat, karena debat adalah perang mulut; orang beradu argumentasi, beradu paham, dan kemampuan persuasi untuk memenagkan pahamnya sendiri. Dalam diskusi, tiap orang diharapkan memberikan sumbangan sehingga seluruh kelompok kembali dengan paham yang telah dibina bersama [10].

\section{Sikap Ilmiah}

Sikap adalah kemampuan menerima atau menolak objek berdasarkan penilaian terhadap objek tersebut [19]. Selaras dengan pendapat dari Suprijono, sikap merupakan kesiapan dan kesediaan seseorang untuk menerima atau menolak suatu objek berdasarkan penilaian terhadap objek itu. Sikap berhubungan dengan pengetahuan dan perasaan seseorang terhadap obyek. Sikap dapat dipelajari dan dapat diubah melalui proses belajar [10].

Sikap ilmiah merupakan salah satu bentuk kecerdasan yang dimiliki oleh setiap individu. Sikap ilmiah siswa pada dasarnya tidak berbeda dengan keterampilan-keterampilan lain (kognitif, sosial, dan psikomotor). Untuk memunculkan sikap ilmiah siswa juga diperlukan sebuah model pembelajaran yang sesuai dengan indikator-indikator yang dimiliki oleh sikap ilmiah siswa itu. Dalam pembelajaran sikap ilmiah siswa sangat diperlukan sikap rasa ingin tahu, bekerja sama secara terbuka, bekerja keras, bertanggung jawab, kepedulian, kedisiplinan dan kejujuran. Ini dikarenakan dengan sikap ilmiah tersebut pembelajaran akan berjalan dengan baik, sehingga mencapai tujuan pembelajaran dan hasil belajar yang diinginkan, dimana siswa diharapkan mampu aktif dan kreatif dalam pembelajaran [20]

\section{Hasil Belajar}

Hasil belajar adalah pola-pola perbuatan, nilainilai, pengertian-pengertian, sikap-sikap, apresiasi dan keterampilan [21]. Hasil belajar sebagai pencapaian kompetensi-kompetensi yang mencakup aspek pengetahuan, keterampilan, sikap, dan nilainilai yang diwujudkan dalam kebiasaan berpikir dan bertindak, hasil belajar merupakan akibat dari suatu proses belajar [14].

Berdasarkan pengertian di atas, peneliti menyimpulkan bahwa hasil belajar adalah perubahan pada diri individu dari segi kognitif, afektif, maupun psikomotor yang didapatkannya sebagai akibat dari suatu proses belajar. Dalam penelitian ini, hasil belajar merupakan perubahan yang terjadi dalam diri individu yang sebelumnya tidak tahu menjadi tahu ditinjau dari aspek pengetahuan akibat dari proses belajar yang ia lakukan atau alami.

Hasil belajar pada penelitian ini mengacu pada revisi taksonomi Bloom, yakni pada ranah kognisi. Adapun ranah kognisi dalam revisi taksonomi Bloom yaitu mengingat, memahami, mengaplikasikan, menganalisis, mengevaluasi, dan mencipta [22].

\section{METODE PENELITIAN}

Jenis penelitian ini adalah penelitian eksperimen, yang merupakan metode penelitian yang digunakan untuk mencari pengaruh perlakuan tertentu terhadap yang lain dalam kondisi yang terkendalikan [19]. Penelitian ini dilaksanakan mulai bulan september 2015 sampai dengan Juli 2016 bertempat di SMAN 1 Mataram. Pada penelitian ini ada tiga variabel yang menjadi fokus penelitian yaitu variabel bebas, variabel terikat dan variabel moderator. Variabel bebas pada penelitian ini adalah metode pembelajaran, variabel terikat adalah hasil belajar fisika siswa, dan variabel moderator adalah sikap ilmiah. Desain penelitian yang digunakan adalah faktorial design $2 \times 2$, faktorial design ini digunakan apabila peneliti mempertimbangkan pengaruh variabel bebas lain (biasanya variabel moderator) dalam penelitiannya [23]. Faktorial design $2 \times 2$ dapat digambarkan seperti pada tabel 2.

Tabel 2. Desain Faktorial $2 \times 2$

\begin{tabular}{|c|c|c|c|}
\hline \multicolumn{2}{|l|}{$\mathrm{A}$} & \multicolumn{2}{|c|}{$\begin{array}{c}\text { Model Problem Based } \\
\text { Learning (B) }\end{array}$} \\
\hline & & $\begin{array}{c}\text { Metode } \\
\text { Eksperimen }\left(\mathrm{B}_{1}\right)\end{array}$ & $\begin{array}{c}\text { Metode } \\
\text { Diskusi } \\
\left(\mathrm{B}_{2}\right)\end{array}$ \\
\hline \multirow{2}{*}{$\begin{array}{l}\text { Sikap } \\
\text { ilmiah } \\
\text { (A) }\end{array}$} & $\begin{array}{l}\text { Tinggi } \\
\left(\mathrm{A}_{1}\right)\end{array}$ & $\mathrm{A}_{1} \mathrm{~B}_{1}$ & $\mathrm{~A}_{1} \mathrm{~B}_{2}$ \\
\hline & $\begin{array}{c}\text { Rendah } \\
\left(\mathrm{A}_{2}\right)\end{array}$ & $\mathrm{A}_{2} \mathrm{~B}_{1}$ & $\mathrm{~A}_{2} \mathrm{~B}_{2}$ \\
\hline
\end{tabular}

Diadaptasi dari Setyosari (2013) 
Keterangan:

A = Sikap ilmiah

$\mathrm{A}_{1}=$ Sikap ilmiah Tinggi

$\mathrm{A}_{2}=$ Sikap ilmiah Rendah

$\mathrm{B}=$ Model Problem Based Learning

$\mathrm{B}_{1}=$ Model Problem Based Learning dengan

Metode Eksperimen

$\mathrm{B}_{2}=$ Model Problem Based Learning dengan Metode Diskusi

Adapun teknik pengambilan sampel menggunakan teknik cluster random sampling yaitu mengambil secara acak sekelompok individu (rumpun/ kelas), bukan mengambil secara acak individu dari populasi yang ada. Dalam penelitian ini yang dijadikan sampel yaitu kelas X MIPA 4 sebagai kelas eksperimen I dengan model problem based learning dengan metode eksperimen dan X MIPA 7 sebagai kelas eksperimen II dengan model problem based learning dengan metode diskusi.

Prosedur dan langkah-langkah yang digunakan dalam melaksanakan penelitian ini mengikuti langkah-langkah pada model pembelajaran problem based learning dengan metode eksperimen dan diskusi. Permasalahan yang dikaji dalam penelitian ini adalah melihat pengaruh model problem based learning dengan metode ekperimen dan diksui terhadap hasil belajar, dan melihat pengaruh sikap ilmiah terhadap hasil belajar, serta melihat interaksi model problem based learning dengan metode eksperimen dan diskusi terhadap hasil belajar fisika siswa. Dengan menggunakan desain faktorial $2 \times 2$ dengan dua sel taksama. Data hasil belajar fisika siswa diperoleh dengan menggunakan instrumen yang telah diuji cobakan dengan mempertimbangkan uji validitas, reliabilitas, tingkat kesukaran, dan daya beda soal, serta menggunakan angket sikap ilmiah siswa yang yang telah diuji cobakan dengan mempertimbangkan uji validitas dan reliabilitas angket. Berdasarkan hasil uji coba diperoleh 30 soal yang baik digunakan untuk tes hasil belajar siswa dan 16 soal angket untuk menguji sikap ilmiah. Analisis data tes hasil belajar siswa menggunakan anava $2 \times 2$ dengan dua sel taksama.

Hasil penelitian berupa deskripsi data hasil belajar fisika siswa dengan menggunakan uji homogenitas, uji normalitas dan uji hipotesis (anava $2 \times 2$ dengan dua sel taksama). Adapun hasil rekapitulasi data sikap ilmiah dan data hasil belajar fisika pada kelas eksperimen I dan kelas eksperimen II pada materi suhu, kalor dan perpindahan kalor dapat dilihat pada tabel berikut ini:

Tabel 3. Data Sikap Ilmiah Siswa Kedua Kelompok Sampel

Data $\quad$ Kelas Eks I $\quad$ Kelas Eks II

\begin{tabular}{lcc}
\hline Jumlah Siswa & 38 & 40 \\
Skor Tertinggi & 62 & 58 \\
Skor & 43 & 44 \\
$\begin{array}{l}\text { Terendah } \\
\text { Rata-rata }\end{array}$ & 52,42 & 50,70 \\
$\begin{array}{l}\text { Jumlah Siswa } \\
\text { kategori } \\
\text { Tinggi }\end{array}$ & 20 & 24 \\
$\begin{array}{l}\text { Jumlah Siswa } \\
\text { kategori } \\
\text { rendah }\end{array}$ & 18 & \\
\hline
\end{tabular}

Berdasarkan Tabel 3 pada kelas eksperimen I diperoleh jumlah siswa kategori sikap ilmiah tinggi sebanyak 20 dan kategori sikap ilmiah rendah sebanyak 18 dengan rata-rata sikap ilmiah 52,42. Pada kelas eksperimen II diperoleh jumlah siswa kategori sikap ilmiah tinggi sebanyak 24 dan jumlah siswa kategori sikap ilmiah rendah sebanyak 16

\begin{tabular}{lcc}
\hline \multicolumn{1}{c}{ Kelas } & Eks I & Eks II \\
& & \\
\hline Jumlah Siswa & 38 & 40 \\
Nilai Terendah & 63 & 57 \\
Nilai Tertinggi & 90 & 90 \\
Rata-rata & 76,50 & 79,83 \\
SD & 7,00 & 6,72 \\
Keterangan & Tuntas & Tuntas \\
\hline
\end{tabular}

dengan rata-rata 50,70.

Tabel 4. Hasil Potess

Hasil posttest siswa pada kelas eksperimen I dan kelas ekserimen II dapat dilihat pada Tabel 4. Berdasarkan tabel 4, diperoleh nilai rata-rata untuk kelas eksperimen I dan kelas eksperimen II masingmasing sebesar 76,50 dan 79,83. Adapun

nilai KKM untuk materi pokok suhu,kalor dan perpindahannya adalah 67 .

Uji normalitas menggunakan rumus chi kuadrat pada taraf signifikan $5 \%$ dengan $d b=k-1$. Hasil perhitungan uji normalitas dapat dilihat pada tabel 5 .

Tabel 5. Hasil Uji Normalitas

\begin{tabular}{lrrrr}
\hline Kelas & $\begin{array}{l}\text { Jumlah } \\
\text { Siswa }\end{array}$ & $\begin{array}{c}\boldsymbol{\chi}^{\mathbf{2}} \\
\text { hitung }\end{array}$ & $\begin{array}{c}\boldsymbol{\chi}^{\mathbf{2}} \\
\text { tabel }\end{array}$ & Kriteria \\
\hline Eks I & 38 & 2,522 & 11,070 & Normal \\
Eks II & 40 & 3,962 & 11,070 & Normal
\end{tabular}

Berdasarkan tabel 5, terlihat bahwa nilai $\chi^{2}$ hitung $<\chi^{2}$ tabel baik pada kelas eksperimen I mapun kelas eksperimen II. Hal ini menunjukan bahwa data hasil belajar IPA-Fisika siswa pada kedua kelas terdistribusi normal.

Hasil perhitungan uji homogenitas hasil belajar IPA-Fisika siswa dapat dilihat pada tabel 6. 
Tabel 6. Hasil Uji Homogenitas

\begin{tabular}{lccccc}
\hline \multicolumn{1}{c}{ SV } & JK & DB & KR & $F_{\text {hitung }}$ & $F_{\text {tabel }}$ \\
\hline Metode & 181.34 & 1 & 181.34 & 3.91 & 1.71 \\
Sikap & 215.44 & 1 & 215.44 & 4.64 & 1.71 \\
Ilmiah & & 1 & 8.55 & 0.18 & 1.71 \\
Intraksi & 8.55 & 1 & & & \\
Dalam & & & & \\
Group (D) & 3433.38 & 74 & 46.40 & & \\
Residu & & & & & \\
Total & 3838.72 & 77 & & & \\
\hline
\end{tabular}

Dari data di atas, diperoleh $F_{\text {hitung }}$ sebesar 0,922 dan $F_{\text {tabel }}$ sebesar 1,71. $F_{\text {hitung }}<F_{\text {tabel }}$ sehingga varian-varian homogen.

Dalam penelitian ini, uji hipotesis dilakukan untuk mengetahui pengaruh perlakuan yang diberikan dan sikap ilmiah yang dimiliki siswa terhadap hasil belajar. Setelah melakukan uji

\begin{tabular}{crrrrc}
\hline Kelas & $\begin{array}{l}\text { Jumlah } \\
\text { Siswa }\end{array}$ & Varian & $\begin{array}{c}F_{\text {hitu }} \\
n g\end{array}$ & $\begin{array}{c}F_{\text {tabe }} \\
l\end{array}$ & Kriteria \\
\hline Eks I & 38 & 48,986 & 0,92 & 1,71 & Homog \\
Eks II & 40 & 45,174 & 2 & en \\
\hline
\end{tabular}

homogenitas dan uji normalitas sampel dari data hasil belajar posttest, diperoleh bahwa siswa berasal dari populasi yang berdistribusi normal dan memiliki varians yang homogen sehingga uji hipotesis yang digunakan adalah uji statistik parametrik. Adapun uji statistik parametrik yang digunakan dalam penelitian ini adalah uji anava dua jalur dengan frekuensi sel tak sama. Hasil analisis uji hipotesis data terhadap hasil belajar siswa dapat dilihat pada Tabel berikut:

Tabel 7. Analisis Hipotesis berikut:

Berdasarkan Tabel 7 didapatkan hasil sebagai

1) Hipotesis 1

Berdasarkan perhitungan pada tabel 4.5 diperoleh $F_{A}=3,91$ sedangkan $F_{\text {tabel }}=1,71$ dengan taraf signifikan 0,05 . Hal ini menunjukkan bahwa $F_{A}>F_{\text {tabel }}$, dengan demikian $H_{01}$ ditolak dan $H_{a 1}$ diterima, artinya Ada pengaruh metode terhadap hasil belajar siswa pada ranah kognitif. Hal ini disebabkan karena pada pembelajaran menggunkan model problem based learning dengan metode eksperimen dan dikusi siswa siswa lebih aktif dalam proses pembelajaran.

2) Hipotesis 2

Pada tabel 4.5 diperoleh $F_{B}=4,64$ sedangkan $F_{\text {tabel }}=1,71$ dengan taraf signifikan 0,05 . Hal ini menunjukkan bahwa $F_{B}>F_{\text {tabel }}$, dengan demikian $H_{02}$ ditolak dan $H_{a 2}$ diterima, artinya ada pengaruh sikap ilmiah terhadap hasil belajar siswa pada ranah kognitif.

3) Hipotesis 3

Pada tabel 4.5 diperoleh $F_{A B}=$ 0,18 sedangkan $F_{\text {tabel }}=1,71$ dengan taraf signifikan 0,05 . Hal ini menunjukkan bahwa $F_{A B}<$ $F_{\text {tabel }}$, dengan demikian $H_{03}$ diterima dan $H_{a 3}$ ditolak, artinya tidak ada interaksi antara metode eksperimen dan diskusi dengan sikap ilmiah terhadap hasil belajar siswa pada ranah kognitif.

Perhitungan dengan menggunakan SPSS 22, didapat hubungan antara sikap ilmiah dengan model problem based learning dengan metode eksperimen dan diskusi terhadap hasil belajar melalui gambar sebagai berikut.

Gambar 1. Hubungan antara Metode Pembelajaran dengan Sikap Ilmiah.

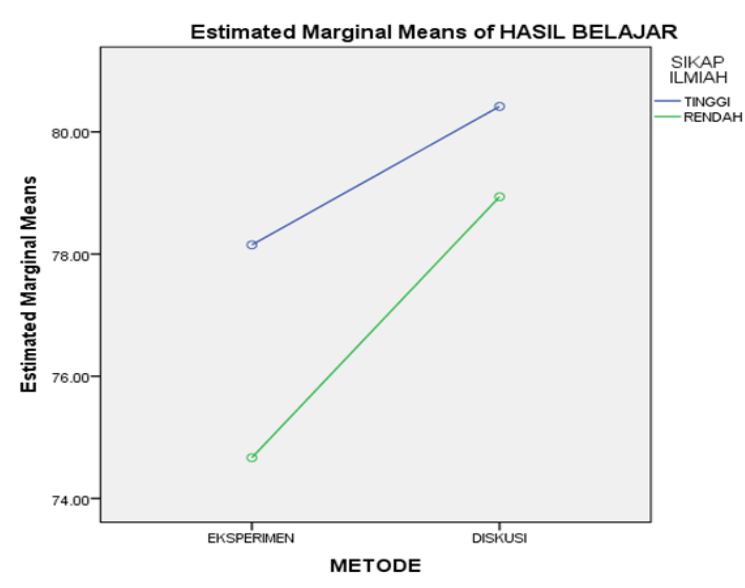

Gambar 1 menunjukkan hubungan sikap ilmiah dan model pembelajaran terhadap hasil belajar. Kedua garis menunjukkan hubungan tingkat sikap ilmiah siswa pada kedua kelas yakni sikap ilmiah tinggi dan sikap ilmiah rendah. Keduanya tidak berpotongan di satu titik melainkan terpisah satu sama lain, artinya tidak ada hubungan atau intraksi antara model pembelajaran dengan metode eksperimen dan diskusi dengan sikap ilmiah terhadap hasil belajar.

Penelitian ini dilakukan di SMA Negeri 1 Mataram pada kelas X MIPA semester 2 tahun ajaran 2015/2016. Pada penelitian ini digunakan dua kelas, satu kelas sebagai kelas eksperimen I, yaitu kelas X MIPA 4 dan satu kelas sebagai kelas eksperimen II, yaitu kelas X MIPA 7. Perlakuan yang diberikan kepada peserta didik kelas eksperimen I adalah model pembelajaran berbasis masalah dengan metode eksperimen dan kelas Eksperimen II diberikan adalah model pembelajaran berbasis masalah dengan metode diskusi. Kedua kelas kemudian dibagi menjadi empat kelompok yaitu siswa yang menggunakan metode eksperimen dengan sikap ilmiah tinggi $\left(A_{1} B_{1}\right)$, siswa yang menggunakan metode eksperimen dengan sikap 
ilmiah rendah $\left(A_{2} B_{1}\right)$, siswa yang menggunakan metode diskusi dengan sikap ilmiah tinggi $\left(A_{1} B_{2}\right)$ dan siswa yang mengunakan metode diskusi dengan sikap ilmiah rendah $\left(A_{2} B_{2}\right)$.

Pengambilan data mengenai sikap ilmiah siswa dilakukan setelah selesai proses pembelajaran untuk menentukan kelompok siswa yang memiliki sikap ilmiah tinggi dan rendah.

\section{Pengaruh Model Pembelajaran Terhadap Hasil Belajar Siswa}

Berdasarkan tabel 4 terlihat nilai rata-rata posttest siswa kelas eksperimen I adalah 76,50 sedangkan nilai rata-rata siswa kelas ekserimen II adalah 79,83. Dari data tersebut terlihat bahwa nilai rata-rata kelas eksperimen II lebih tinggi daripada nilai rata-rata kelas eksperimen I, artinya bahwa hasil belajar Fisika siswa kelas eksperimen II lebih tinggi daripada kelas eksperimen I. Selain itu, berdasarkan analisi dengan menggunakan anava dengan bantuan Ms. Excel 2010 diperoleh $\mathrm{F}_{\text {hitung }}$ untuk hipotesis pertama lebih besar dari pada $F_{\text {tabel }}$ hasil ini menunjukkan bahwa model problem based learning dengan metode eksperimen dan diskusi yang diterapkan pada kedua kelas berpengaruh terhadap hasil belajar fisika siswa sehingga $\mathrm{H}_{a 1}$ diterima, artinya ada pengaruh model problem based learning dengan metode eksperimen dan diskusi terhadap hasil belajar fisika siswa. Ada beberapa faktor yang menyebabkan model problem based learning dengan metode eksperimen dan diskusi berpengaruh terhadap hasil belajar, diantaranya dengan penerapan model problem based learning yang berbasis masalah sehari-hari sehingga siswa lebih mudah dalam menyelesaikan permasalahan yang disajikan karena sudah mengenal permasalahan yang dihadapi serta siswa lebih aktif dalam proses pembelajaran.

Model pembelajaran berbasis masalah memberikan kesempatan kepada semua siswa untuk aktif dalam proses pembelajaran, terlebih lagi untuk menyelesaikan permasalahan yang disedikan dalam proses pembeajaran dengan cara melakukan eksperimen dan diskusi sehingga siswa dapat membuktikan sendiri dengan melakukan sendiri proses percobaan untuk membuktikan serta melakukan diskusi untuk menyelesaikan permasalahan yang telah disediakan dalam Lembar Kerja Siswa (LKS) dan Lembar Diskusi Siswa (LDS). Hal ini tentunya memberikan pengaruh terhadap hasil belajar fisika siswa yang dapat dibuktikan dengan nilai rata-rata kedua sampel berada diatas KKM. Nilai rata-rata kelas ekperimen I dan kelas eksperimen II berturut-turut adalah 76,50 dan 79,83 lebih besar dari nilai KKM yaitu 67.

Berdasarkan nilai rata-rata antara kelas eksperimen I dan ekserimen II didapatkan nilai rata- rata kelas eksperimen II lebih tinggi dibandingkan dengan kelas eksperimen II. Beberapa faktor yang menyebabkan hasil belajar Fisika siswa pada kelas eksperimen II lebih tinggi daripada kelas eksperimen I, salah satunya adalah diterapkannya model problem based learning dengan metode diskusi kelas eksperimen II. Penerapan model problem based learning dengan metode diskusi dalam proses pembelajaran memberikan dampak pada siswa yaitu, siswa menjadi lebih aktif selama kegiatan pembelajaran, siswa leluasa mengungkapkan ide pemikiranya dan siswa lebih cenderung antusias dalam belajar karena prinsip model problem based learning dengan metode diskusi menekankan masalah pada awal pembelajaran dan mereka diharapkan mampu untuk menyelesaikan masalah yang diberikan dengan cara diskusi bersama kelompok serta mendiskusikan soal-soal yang berkaitan dengan masalah yang diberikan. Adapun masalah yang diberikan selalu terkait dengan kehidupan sehari-hari siswa, dengan demikian pikiran siswa lebih terbuka dan mampu menghubungkan pelajaran fisika dengan kehidupan sehari-hari dan menjadikan hasil belajar siswa lebih baik dari sebelumnya. Hal ini sejalan dengan hasil penelitian bahwa model problem based learning dengan metode diskusi berpengaruh terhadap hasil belajar siswa [24].

Adapun pada kelas Eksperimen II menggunakan model problem based learning dengan metode eksperimen. Model problem based learning dengan metode eksperimen adalah model pembelajaran yang berbasis masalah dengan metode penyelesaiaan dengan eksperimen, model pembelajaran berbasis masalah memberikan kesempatan kepada siswa untuk lebih aktif terlebih dengan metode eksperimen degan menggunakan model problem based learning dengan metode eksperimen berpengaruh terhadap hasil belajar hal ini sejalan dengan hasil penelitian [25] Jadi, siswa menyelesaikan permasalahan dengan menggunakan eksperimen, antusiasme siswa dalam belajar sangat tinggi karena proses belajar yang berbeda dari sebelumnya. Hasil yang didapatkan ternyata menggunakan model problem based learning dengan metode diskusi jauh lebih efektif dari ada menggunakan model promlem based learning dengan metode eksperimen hal ini dikarenakan pada saat proses pembelajaran kelas eksperimen II lebih berorientasi terhadap diskusi soal yang berkaitan dengan masalah yang diberikan sehingga memberikan pelatihan mengerjakan soal lebih dari kelas ekserimen I.

2. Ada Pengaruh Sikap Ilmiah Terhadap Hasil Belajar siswa

Berdasarkan tabel 7 hasil analisis menunjukkan bahwa $F_{\text {hitung }}$ lebih besar dari pada $\mathrm{F}_{\text {tabel }}$ sehingga $\mathrm{H}_{\mathrm{a} 2}$ diterima, maka terdapat pengaruh sikap ilmiah 
terhadap hasil belajar siswa. Ada beberapa faktor yang menyebabkan sikap ilmiah siswa berpengaruh terhadap hasil belajar fisika siswa. Faktor yang dimakasud adalah indikator, indikator sikap ilmiah memberikan pengaruh besar terhadap hasil belajar seperti antusias dalam mencari jawaban, tidak manipulasi data, menghargai pendapat teman, dan bekerjasama dalam kelompok ini dilakukan pada saat proses pembelajaran berlangsung sehingga memberikan pelatihan serta pembiasaan untuk menyelesaikan soal dengan baik hal ini dibuktikan dengan hasil analisis data sikap ilmiahyang terdapat pada tabel 3 bahwa hasil belajar siswa yang mempunyai sikap ilmiah tinggi mempunyai rerata yang lebih besar dibanding siswa yang mempunyai sikap ilmiah rendah yaitu baik dikelas eksperimen I maupun di kelas eksperimen II. Hal ini membuktikan bahwa siswa yang memiliki sikap ilmiah tinggi akan memberikan pengaruh yang lebih besar terhadap hasil belajar jika dibandingkan dengan siswa yang mempunyai sikap ilmiah rendah. Hal ini sejalan dengan hasil penelitian terdapat pengaruh sikap ilmiah terhadap hasil belajar siswa [26]. Namun ada beberapa siswa yang memiliki sikap ilmiah rendah namun memiliki nilai kognitif yang tinggi, ini dikarenakan pada saat pengambilan data sikap ilmiah siswa tersebut kurang serius dalam mengisi angket yang diberikan. Namun, ketika diberikan soal ujian siswa tersebut sangat serius dalam mengerjakan soal yang diberikan.

\section{Interaksi Model Problem Based Learning dengan metode eksperimen dan diskusi serta Sikap Ilmiah terhadap Hasil Belajar Siswa.}

Hasil analisis menunjukkan bahwa $\mathrm{F}_{\text {hitung }}$ lebih kecil dari pada $\mathrm{F}_{\text {tabel }}$ sehingga hipotesis 3 ditolak, ini menunjukkan bahwa tidak terdapat interaksi antara penggunaan model problem based learning dengan metode eksperimen dan diskusi serta sikap ilmiah. Model problem based learning dengan metode eksperimen dan diskusi serta sikap ilmiah berpengaruh secara signifikan terhadap hasil belajar fisika, namun diantara keduanya tidak memiliki interaksi untuk saling mempengaruhi hasil belajar secara bersama-sama. Jika tidak terjadi interaksi maka tidak diperlukan uji komparasi ganda antar sel anava, dengan demikian peneliti tidak melakukan uji lanjut [27].

Hasil pengujian menggunakan SPSS 22, berdasarkan gambar 1 grafik hubungan model pembelajaran dan sikap ilmiah, diperoleh bahwa tidak terjadi interaksi antara model pembelajaran dan sikap ilmiah terhadap hasil belajar. Hal ini ditunjukkan dari grafik dengan tidak adanya perpotongan antara sikap ilmiah tinggi dan rendah. Berdasarkan teori statistik bahwa suatu variabel dapat dikatakan berinteraksi dengan variabel lainnya jika pada grafik terdapat titik temu [28].

Siswa yang menggunakan model problem based learning dengan metode eksperimen yang memiliki sikap ilmiah tinggi memiliki hasil belajar yang lebih baik dari padayang memiliki sikap ilmiah rendah. Siswa yang memiliki sikap ilmiah tinggi pada kelas eksperimen II dengan model problem based learning dengan metode diskusi juga memiliki hasil belajar lebih baik dari pada yang memiliki sikap ilmiah rendah. Ini membuktikan bahwa interaksi antara sikap ilmiah dan model problem based learning dengan metode eksperimen dan diskusi tidak tampak pada hasil belajar yang diperoleh siswa. Pada gambar 4.3, terlihat bahwa tidak ada titik temu antara kedua garis yang menghubungkan kedua variabel yakni sikap ilmiah tinggi dan sikap ilmiah rendah sehingga jelas bahwa model problem based learning dengan metode eksperimen dan diskusi serta sikap ilmiah tidak saling berinteraksi terhadap hasil belajar.

\section{KESIMPULAN}

Berdasarkan data yang diperoleh dan hasil dari analisis data yang telah dikemukakan dapat disimpulkan beberapa hal, yaitu:

1. Terdapat pengaruh model Problem Based Learning (PBL) dengan metode eksperimen dan diskusi terhadap hasil belajar fisika. Model PBL dengan metode diskusi memberikan pengaruh yang lebih baik dari pada menggunakan model PBL dengan metode eksperimen.

2. Terdapat pengaruh sikap ilmiah siswa terhadap hasil belajar fisika. Hasil belajar fisika siswa yang mempunyai sikap ilmiah tinggi akan memberikan pengaruh yang jauh lebih baik dibanding dengan siswa yang mempunyai sikap ilmiah rendah.

3. Tidak terdapat interaksi antara model Problem Based Learning (PBL) dengan metode eksperimen dan diskusi dengan sikap ilmiah siswa terhadap hasil belajar fisika siswa.

\section{UCAPAN TERIMA KASIH}

Terima kasih penulis sampaikan kepada Ibu Satutik Rahayu, SPd., M.Pd., selaku dosen pembimbing skrisi I dan Ibu Hikmawati, S.Pd., M.Pd., selaku dosen pembimbing skripsi II yang dengan sabar membimbing, memberikan arahan, dan nasehat sehingga penyusunan skripsi ini dapat terselesaikan dengan baik. Tak lupa pula penulis mengucapkan terima kasih kepada Bapak Dr. H. Wildan, M.Pd., selaku Dekan FKIP Universitas Mataram. Bapak Dr. Drs. Karnan, M.Si., selaku Ketua Jurusan Pendidikan MIPA. Bapak Dr. Ahmad Harjono, S.Si., M.Pd., 
selaku Ketua Program Studi Pendidikan Fisika, Bapak Drs. H. Lalu Fatwir Uzali, S.Pd, M.Pd., selaku Kepala SMAN 1 Mataram yang telah mengizinkan sekolahna untuk dijadikan tema penelitian. Ibu Dra. Sri Murni, M.Pd., selaku guru mata pelajaran IPA Fisika di SMAN 1 Mataram yang telah memberikan bimbingan selama penelitian, serta semua pihak lain yang telah membantu penelitian ini.

\section{REFERENSI}

[1] Samani, M., dan Hariyanto. 2013. Konsep dan Model Pendidikan Karakter. Bandung: PT Remaja Rosdakarya.

[2] Arsyad, A. 2011. Media Pembelajaran. Jakarta: PT Raja Grafindo Persada.

[3] Suprijono, A. 2013. Cooperative Learrning. Surabaya: Pustaka Pelajar.

[4] Kosasih, E. 2014. Strategi Belajar dan Pebelajaran Implementasi Kurikulum 2013. Bandung: Yrama Widya.

[5] Gunawan. 2015. Model Pembelajaran Sains Berbasis ICT. Mataram: FKIP Universitas Mataram.

[6] Lestari, P. A. S., Rahayu, S., dan Hikmawati. 2015. Profil Siswa Kelas X SMKN 4 Mataram pada Materi Pokok Suhu, Kalor, dan Perpindahan Kalor. Jurnal Pendidikan Fisika dan Teknologi. Vol. 1. No. 3, hal. 146-153.

[7] Susanto, D.. Sutrio., dan Wahyudi. 2015. Pengaruh Pembelajaran Berbasis Masalah melalui Metode Eksperimen Terhadap Keterampilan Proses Sains Fisika Siswa SMA Negeri 1 Selong Tahun Pelajaran 2014/2015. Jurnal Pendidikan Fisika dan Teknologi. Vol. 1. No. 3, hal. 161-165.

[8] Djamarah, S. B. dan Zain, A. 2009. Strategi Belajar Mengajar. Jakarta: Rineka Cipta.

[9] Rahman, T. 2006. Pendekatan dan Metode dalam Program Pembelajaran Praktikum. Bandung. Jurusan Pendidikan Biologi UPI.

[10] Setyowati, M. Endardo, D., dan Prihadi, S. 2013. Desain Model Problem Based Learning dengan Metode Diskusi dan Insiden Ditinjau dari Kualitas Proses dan Hasil Belajar Geografi pada Kompetensi Dasar Hubungan Manusia dan Lingkungan Akibat Dinamika Atmosfer. Skripsi. Universitas Sebelas Maret Surakarta.

[11] Nurqomariah., Gunawan., dan Sutrio. 2015. Pengaruh Problem Based Learning dengan Metode Eksperimen terhadap Hasil Belajar IPA Fisika Siswa Kelas VII SMP Negeri 19 Mataram Tahun Pelajaran 2014/2015. Jurnal Pendidikan Fisika dan Teknologi. Vol. 1. No. 3, hal. 173-179.

[12] Samani, M., dan Hariyanto. 2013. Konsep dan Model Pendidikan Karakter. Bandung: PT Remaja Rosdakarya.

[13] Abidin, Y. 2014. Desain Pembelajaran dalam Konteks Kurikulum 2013. Bandung: PT Refika Aditama.

[14] Tika, I. K. 2008. Penerapan Problem Based Learning Berorientasi Penilaian Kinerja dalam Pembelajaran Fisika untuk Meningkatkan Kompetensi.

[15] Sagala, S. 2009. Konsep dan Makna Pembelajaran. Bandung: Alfabeta.
[16] Roestiyah, N.K. 2012. Strategi Belajar Mengajar. Jakarta: Rineka Cipta.

[17] Isjoni. 2009. Pembelajaran Kooperatif. Yogyakarta: Pustaka Pelajar.

[18] Gayatri, K. 2009. Penggunaan Metode Diskusi untuk Meningkatkan Hasil Belajar IPA pada Siswa Kelas IV SDN SAMBI 4 Tahun Pelajaran 2009/2010. Skripsi. Universitas Sebelas Maret Surakarta.

[19] Sudjana, N. 2011. Penilaian Hasil Proses Belajar Mengajar. Bandung: PT Remaja Rosadakarya.

[20] Fakhruddin. 2010. Sikap Ilmiah Siswa dalam Pembelajaran Fisika dengan Menggunakan Media Komputer Melalui Model Kooperatif Tipe STAD Pada Siswa Kelas $\mathrm{X}_{3}$ SMA Negeri Bangkinan Barat. Jurnal Geliga Sains. Universitas Riau.

[21] Trianto. 2009. 2011. Model-Model Pembelajaran Inovatif Berorientasi Konstruktivistik. Jakarta: Prestasi Pustaka.

[22] Anderson, L.W., Krathwohl, D.R. 2001. A Taxonomy for Learning, Teaching, and Assessing: A Revision of Bloom's Taxonomy of Educational Objectives. New York: Longman.

[23] Setyosari, P. 2013. Metode Penelitian Pendidikan dan Pengembangan. Jakarta: Prenadamedia.

[24] Mudalara, I.,P. 2012. Pengaruh Model Pembelajaran Ingkuiri Bebas Terhadap Hasil Belajar Kimia Siswa Kelas XI IPA SMA Negeri 1 Gianyar Ditinjau dari Sikap Ilmiah. Jurnal Penelitian Pascasarjana Undiksha. Vol. 2. No. 2.

[25] Budiyono. 2004. Statistika Untuk Penelitian. Surakarta: Sebelas Maret University.

[26] Cardinal, R. N. 2004. Anova In Practice And Complex Anova Designs. United States of America: Thompson Learning.

[27] Kementrian Pendidikan dan Kebudayaan. 2014 Implementasi Kurikulum 2013. Jakarta: Pusat Kurikulum dan Pembukuan.

[28] Saregar, A., Sunarno, Widha., dan Cari. 2013. Pembelajaran Fisika Kontekstual melalui Metode Ekperimen dan Demostrasi Diskusi menggunkaan Multimedia Intraktif ditinjau dari Sikap Ilmiah dan Kemampuan Verbal Siswa. Jurnal FKIP Universitas Negeri Semarang. ISSN: 2252-7893, Vol.2, No.2, 2013, hal. 100113.

\section{BIOGRAFI PENULIS}

Muhamad Khairul Azmi, lahir di Pesanggrahan Lombok Timur, tanggal 24 April 1994. Penulis menelesaikan bangku pendidikan SD di SDN 6 Montong Betok, Melanjutkan ke SMPN 1 Montong Gading, serta melanjutkan ke SMAN 1 Sikur. Penulis, melanjutkan Studi di Universitas Mataram pada FKIP mengambil Studi Pendidikan Fisika dan lulus tahun 2016. 